\title{
The Properties of Powders.
}

CONSIDERABLE interest attaches, both on the scientific and on the technical side, to the study of powders which are sufficiently fine to differ markedly in their properties from massive crystals, while they are sufficiently coarse to differ equally widely from colloidal suspensions. One important property of powders, namely the caking of salts (a phenomenon which was responsible for the disastrous explosion at Oppau), was discussed at a joint meeting of the London Section of the Society of Chemical Industry and of the Faraday Society on March I, 1920. This has now been followed up by a joint meeting of the Faraday Society and the Oil and Colour Chemists' Association, held at Burlington House on March 9 last, when the material presented was sufficiently abundant to call for an adjourned discussion on March 23.

The principal subject discussed was the grading of powders by elutriation, a process which has proved of great value to the geologist and to the agriculturist, of the Finer Constituents of Sedimentary Rocks," in which the geological applications of elutriation are described. One of the principal problems here is to devise a method of summarising the mechanical analysis of a sediment, containing particles of many different sizes, in such a way that the results can be expressed by means of one or two numbers. The use of a single number is impracticable, since in addition to the fineness of the material, its uniformity must be represented by a separate coefficient. A satisfactory solution appears to have been provided by Dr. H. A. Baker, who makes use of the term "equivalent grade" to express the average of the diameters of the particles, whilst a "grading factor" serves to express the deviation of the particles from the average. Prof. Boswell has had much experience in the practical application of elutriation, particularly in the mechanical analysis of the sands and rocks used in glass-making, and his notes on the difficulties and errors encountered in the process are of considerable

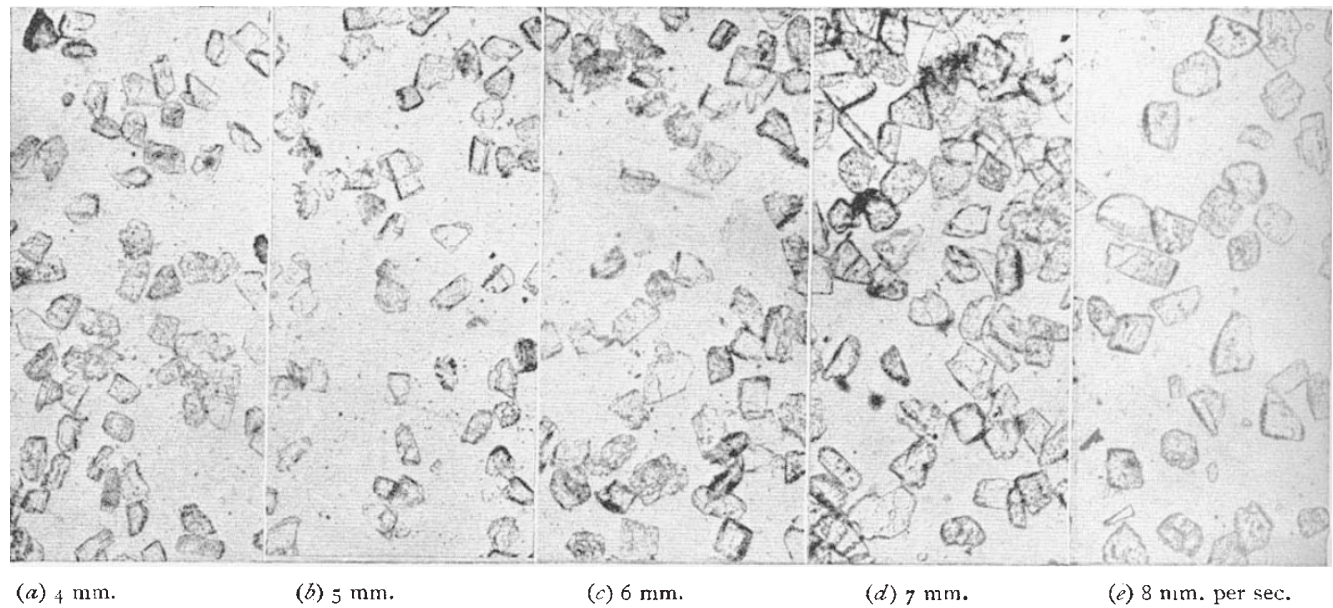

Fig. I. - Elutriation of Barytes. $(\times 50$.

as well as to the manufacturer of pigments and of food products where artificial grinding is required in order to produce minute subdivision.

The formal papers presented to the meeting were four in number. Prof. Lowry and Mr. L. P. MacHatton, in a paper on "The Grading of Powders by Elutriation," submitted a new series of experimental data as to the diameter of the particles of barytes and of quartz which are just lifted by a vertical current of water at velocities ranging from 4 to $8 \mathrm{~mm}$. per second (Fig. I). The data for barytes are more concordant than those for quartz, probably because the particles of barytes are, in the main, cleavage-fragments of fairly uniform shape, whilst in the case of quartz the natural conchoidal fracture produces much more irregular particles. In the case of barytes it was possible to show that the use of a vertical tube one inch in diameter lifts particles which are 5 per cent. smaller than when a half-inch tube is used; but the grading is also much more uniform as a result of the more uniform velocity of the water in the tube. The temperature-coefficient was also measured and shown to correspond with a decrease of $0: 4$ per cent. only in the diameter of the particles for each degree of rise of temperature ; and an empirical relationship was deduced between the velocity of the water and the size of the grain of barytes lifted by it.

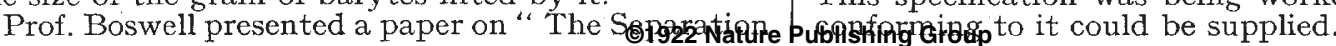

value. Dr. J. W. French, who has made use of water-separation for the grading of emery and carborundum for use as polishing powders in grinding lenses, contributed to the same meeting a paper on "Abrasives and Polishing Powders for Glass."

Dr. R. S. Morrell, the president of the Oil and Colour Chemists' Association, opened the discussion, by emphasising the value of elutriation to colourusers, as a method of controlling the materials which they purchased from the pigment-makers and grinders.

The adjourned discussion was opened by Dr. C. A. Klein of the Brimsdown White Lead Company. While Prof. Lowry had been working with a range of sizes down to about $0.07 \mathrm{~mm}$., Dr. Klein's work had dealt with grades in which this was more nearly the maximum than the minimum size of the particles; they therefore presented greater experimental difficulties, more particularly as a result of flocculation. In addition to describing a number of points in connection with the practical use of the elutriator, Dr. Klein stated that a specification had actually been put forward by a user of pigments who was calling for the supply of some hundreds of tons of a product in which the largest particles. would have a diameter not exceeding $O \cdot I \mathrm{~mm}$., whilst the average size of the particles was not to exceed $0.027 \mathrm{~mm}$ This specification was being worked to and material 
Prof. Lowry then showed " A New Elutriator for Rapid Use," especially adapted for use in factories. The gravimetric determination of the residue of coarse particles is here replaced by a simple measurement of the height of the column of grit in a narrow tube, and tests can therefore be made even where the ordinary facilities of a chemical laboratory are not available. Lieut.-Col. J. V. Ramsden, of Shropshire Mines Ltd., stated (at the previous meeting) that with the help of this instrument he had been able, whilst using the same grinding plant, to reduce the residue in ground barytes from 6 per cent. to 0.5 per cent. Prof. Lowry added that since this instrument was introduced two years ago the relative merits of British and imported samples of ground barytes had been reversed completely, with the result that the finest products that he had tested recently were of British manufacture.

Mr. W. J. Palmer referred to the practical importance of fine grinding in the paint industry, both in the preparation of enamels and as a means of preventing the hard setting of paint in cans which were sent abroad or stored for some years before being used. Mr. Noel Heaton contradicted the general impression that the ball-mill tends to produce round particles, since when the glass was ground in this way, even to 0.003 or $0.004 \mathrm{~mm}$. diameter, the particles when examined by the microscope had the normal appearance of broken glass and were not in the least degree rounded.

Dr. R. Lessing mentioned some applications of elutriation in connection with the fire-brick, coal and metallurgical industries. Its application to metallurgy was described by $\mathrm{Mr}$. Holman in connection with tin slimes, where a loss of ro to $x_{5}$ per cent. was traced to the carrying away of very fine particles in a current of water.

Mr. Tate, of the Government Laboratory, referred to elutriation as a process of analysis in the separation of cocoa from husk in the ground product; a paper on this aspect of the subject was also submitted by Mr. R. Whymper of Messrs Peek, Frean \& Company.

Mr. B. A. Keen, of Rothamsted, criticised the method of elutriation as applied to the mechanical analysis of soils, largely on the ground that the shape of the particle was as important as the size in determining the velocity of water required to lift it. In dealing with very fine particles the simpler process of sedimentation was to be preferred.

Prof. Porter, the President of the Faraday Society, in closing the discussion, referred to centrifuging as a means of grading fine powders, and commented on the relationship which Prof. Lowry had put forward between velocity and grain-size. He also referred to the utility of the discussion and especially to the value of bringing together workers from different fields, who could present information which, although well known to one section of individuals, might not be known at all to other groups represented at the meeting.

\section{The International Petroleum Commission.}

$A^{\mathrm{T}}$ the ninth annual General Meeting of the Institution of Petroleum Technologists, held on March I4, Prof. J. S. S. Brame delivered his presidential address, taking for his subject the proposals for the re-establishment of the International Petroleum Commission. International Petroleum Congresses were held in 1900 , 1904, and 1908 , and committees were appointed to establish methods of testing products. Little was actually achieved, and in I909 an International Petroleum Commission of wider scope was established. The organisation of an English National Section was referred to the Institution of Petroleum Technologists by Engler and Ubbelohde, but the intended meeting of the Commission at Bucharest in I9I4 was prevented by the outbreak of war.

At the first annual meeting of the Petroleum Products section of the Société de Chimie Industrielle at Paris in I92I, M. Schmitz suggested the reconstitution and endowment of this Commission to be centred at the University of Strasburg. He spoke somewhat bitterly of the Americans "profiting by the general disorganisation to seek to abandon the analytical methods previously decided upon, in favour of their own."

Prof. Brame expressed grave doubts as to the wisdom and the justice of $M$. Schmitz's address. $\mathrm{He}$ could not believe that the largest oil-producing country, which had created such splendid organisations as the Bureau of Mines and the American Society for Testing Materials, was likely to depart from the methods of oil analysis it had elaborated and adopted. He outlined the development of these Institutions and the standard methods of petroleum testing they had recommended, and spoke of the cordial relationship between the Standardisation Committee of the Institution of Petroleum Technologists and these American organisations, from which collaboration he hoped would result an agreed system of nomenclature and specifications of the greatest mutual advantage. Such agreement he considered of much greater value to the two countries having by far the largest interests in petroleum than could be gained by the reinstitution of an International Petroleum Commission.

\section{Facilities for Foreign Students in American Colleges and Universities.}

THE Bureau of Education of the Government of the United States have issued under the above title, as Bulletin No. 39 of 1920 , a revised and enlarged edition of a valuable handbook by Dr. S. P. Capen

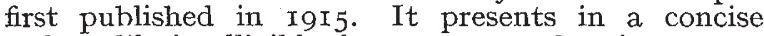
and readily intelligible form a comprehensive survey of a subject concerning which few people in this country have more than a very fragmentary knowledge. After a brief account of the organisation of education of all grades and a historical summary of the college and university systems, the Bulletin gives a description of the parts and working of the typical university and draws a comparison between American and other educational institutions. Next follow particulars of the cost of living and travel, athletics, clubs, etc., and lists of institutions of collegiate or professional grade located in the principal metropolitan centres of higher education, namely, New York, Chicago, Philadelphia, St. Louis, Boston, Baltimore, San Francisco, New Orleans, and Washington. Forty-five pages are devoted to a detailed definition of the requirements of the College Entrance Examination Board, an organisation formed by some 3o colleges together with the principal associations of colleges and secondary schools, which holds examinations in almost every State and in several foreign countries, including Canada, England, and France. 